\title{
Extraversion, secure attachment dan perilaku cyberbullying
}

\author{
Triantoro Safaria* \& Irfani Rizal \\ Fakultas Psikologi, Universitas Ahmad Dahlan, Yogyakarta
}

\begin{abstract}
Abstrak
Riset-riset sebelumnya menunjukkan bahwa perbedaan individual seperti kepribadian dan gaya attachment dapat memprediksi perilaku bullying dan cyberbullying. Meski demikian, masih ditemukan adanya inkonsistensi dalam temuan-temuan sebelumnya. Penelitian ini menguji apakah dimensi kepribadian extraversion dan secure attachment berperan dalam munculnya perilaku cyberbullying. Partisipan dalam penelitian ini berjumlah 199 siswa SMP. Analisis regresi digunakan untuk menguji hipotesis yang diajukan. Hasil penelitian ini menunjukkan bahwa rendahnya skor extraversion memprediksi tingginya skor cyberbullying. Sementara itu rendahnya skor secure attachment memprediksi tingginya skor cyberbullying. Rekomendasi dan saran dijelaskan lebih lanjut dalam artikel ini.
\end{abstract}

Kata kunci: cyberbullying, extraversion, secure attachment

\begin{abstract}
Previous works have demonstrated that individual differences such as personality and attachment style may predict bullying and cyberbullying behavior. However, there is still some inconsistency regarding previous findings. Present study examines whether extraversion and secure attachment play a role in the emergence of cyberbullying behavior. The participants in this study were 199 junior high school students. Regression analysis was used to test the proposed hypothesis. The results of this study indicated that extraversion has a negative significant relationship with cyberbullying behavior and secure attachment has a positive significant relationship with cyberbullying behavior. Recommendations and suggestions are explained further in the article.
\end{abstract}

Keywords: cyberbullying, extraversion, secure attachment

\section{Pendahuluan}

Kemajuan teknologi Internet memberikan banyak manfaat positif, seperti memudahkan siswa untuk menyelesaikan tugas sekolah, berkomunikasi dengan teman sebaya, bekerja sama, mendorong berbagai ide dalam pembelajaran kooperatif, meningkatkan sikap tentang belajar sekaligus meningkatkan rasa ingin tahu dan konsep diri (Wigunadkk, 2018; Quarshie, 2012; Lee, \& Shin, 2017; Wang \& Chang, 2010). Selain dampak positif, kemajuan teknologi informasi juga memunculkan masalah baru, salah satunya adalah cyberbullying (Peled, 2019; Macaulay, Betts, Stiller, \& Kellezi, 2018; Wong, \& McBride, 2018). Cyberbullying adalah setiap perilaku agresif yang menghina, mempermalukan, dan mengancam orang lain yang dilakukan melalui media internet oleh individu atau sekelompok orang secara berulang yang bertujuan untuk menyakiti, menghina, dan menimbulkan ketidaknyamanan pada orang lain (Tokunaga, 2010; Peter \& Petermann, 2018). Penelitian ini bertujuan untuk menguji apakah extraversion dan secure attachment berperan

Naskah masuk: 15 April 2019

Naskah diterima: 12 Juli 2019 dalam mendorong munculnya perilaku cyberbullying pada remaja.

Beberapa penelitian terdahulu menunjukkan cyberbullying victimization memiliki hubungan dengan ketergantungan alkohol, penggunaan ganja, perilaku kesehatan menyimpang, kecenderungan bunuh diri dan frekuensi perilaku seksual tidak sehat (Peled, 2019; Graham \& Wood 2019; Brailovskaia, Teismann, \& Margraf, 2018; Watts, Wagner, Velasquez \& Behrens, 2017). Selanjutnya kombinasi dari physical bullying dan cyberbullying menghasilkan dampak yang lebih berat terhadap perilaku berisiko yang menyimpang (Graham \& Wood, 2019). Cyberbullying victimization juga berkorelasi dengan ide bunuh diri/bunuh diri (Brailovskaia, dkk, 2018), serta simptom depresi (Hong, dkk, 2018). Gradinger, Strohmeier, dan Spiel (2009) menemukan korban cyberbullying memiliki penyesuaian diri yang buruk seperti simptom depresi, somatik, dan perilaku agresif. Penelitian Baker dan Tanrikulu (2010) juga menemukan simptom depresi pada remaja korban cyberbullying. Namun kejadian cyberbullying yang terjadi sesekali memiliki dampak psikologis negatif

*Fakutas Psikologi, Universitas Ahmad Dahlan, Yogyakarta Jl. Kapas 9, Semaki, Umbulharjo, Yogyakarta 55166. Email: triantoro.safaria@psy.uad.ac.id 
yang lebih rendah dibandingkan dengan kejadian yang terus menerus (Tokunaga, 2010).

Penelitian yang dilakukan Safaria (2015) menemukan bahwa dari 102 siswa, (14,28\%) siswa belum pernah mengalami cyberbullying. Banyak siswa mengalami cyberbullying melalui Facebook $(27,5 \%)$, Twitter $(12,7 \%)$ dan SMS (12,7\%). Sisanya siswa mengalami cyberbullying melalui SMS, Twitter, Youtube dan Facebook (33.6\%). Penelitian Ditch the Label (2013) yang merupakan salah satu lembaga anti bullying terbesar di Inggris menunjukkan hasil sebagai berikut: 7 dari 10 remaja menjadi korban cyberbullying, $37 \%$ remaja sering mengalami cyberbullying, 20\% remaja mengalami cyberbullying ekstrem setiap hari, Facebook, Ask.FM dan Twitter ditemukan menjadi sumber yang paling mungkin untuk melakukan cyberbullying, remaja laki-laki dan remaja perempuan sama-sama berisiko mengalami cyberbullying. Studi yang dilakukan oleh Leung, Wong, dan Farver (2018) menemukan dari 312 mahasiswa Hong Kong Chinese, 58\% menjadi pelaku cyberbullying sedangkan 68\% menjadi korban cybervictimized. Data-data di atas menunjukkan bahwa permasalahan cyberbullying telah terjadi secara global dan menjadi masalah serius yang harus diatasi.

\section{Extraversion dan Cyberbullying}

Ada beberapa faktor yang memengaruhi cyberbullying yaitu antara lain bullying tradisional karakteristik kepribadian, persepsi terhadap korban, strain dan peran interaksi orangtua dan anak (Disa, 2011). Salah satu faktor yang memengaruhi cyberbullying adalah karakteristik kepribadian. Camodeca dan Goosens (2005) memaparkan bahwa karakteristik pelaku cyberbullying memiliki kepribadian yang dominan dan senang melakukan kekerasan, cenderung temperamental, impulsif, dan mudah frustrasi. Selain itu penelitian yang lalu menunjukkan bahwa kecenderungan kepribadian psikopati (Gibb \& Devereux, 2014), rendahnya empati (Zych, dkk, 2017), rendahnya agreeableness dan conscientiousness (Pallesen et al., 2017; Khosa, 2016) menjadi karakteristik kepribadian pelaku cyberbullying.

Individu yang memiliki kepribadian ekstravert merupakan individu yang out going dan sangat sosial. Mereka menyukai berkumpul dengan orang, bertemu dengan orang baru, suka bicara (talkative), mudah menyesuaikan diri dengan lingkungan sosial baru (Murphy, Eduljee, Croteau, \& Parkman,, 2017). Kelemahan dari individu yang extraversion ini adalah mereka cenderung berbicara tanpa memikirkan konsekuensinya, impulsif, lebih suka bertindak dari pada berpikir dan melakukan refleksi. Hal lainnya adalah mereka menjadi agak sulit untuk fokus pada satu tugas tertentu (Riccelli, Toschi, Nigro, Terracciano, \& Passamonti, 2017). Kelemahan individu yang extraversion ini sepertinya mendorong mereka mudah terlibat dalam perilaku cyberbullying. Karakteristik seperti berbicara tanpa memikirkan konsekuensinya, impulsif, lebih suka bertindak dari pada berpikir dan melakukan refleksi, mendorong mereka mudah terlibat dalam perilaku cyberbullying. Ada kemungkinan impulsivitas individu yang extravert ini menjadi salah satu sifat yang mendorong mereka mudah mem-bully orang lain di dunia maya, ketika terjadi konflik atau situasi yang membuat mereka frustrasi.

Penelitian White, Fields, Hall, dan White (2016) menunjukkan bahwa karakteristik cyberbullying sama dengan bullying yaitu memiliki kepribadian extraversion yang tinggi. Selain itu Satalina (2014) menemukan kepribadian extraversion yang tinggi memiliki kecenderungan untuk melakukan cyberbullying. Demikian juga penelitian Alonso dan Romero (2017) yang menemukan skor neuroticism yang tinggi pada aggressor-victims cyberbullying. Penelitian yang dilakukan oleh Krisminanti (2015) menemukan kepribadian big five berhubungan negatif dengan kecenderungan remaja melakukan cyberbullying, namun dimensi extraversion tidak berhubungan dengan kecenderungan remaja melakukan cyberbullying dan keterbukaan terhadap pengalaman berhubungan negatif dengan kecenderungan remaja melakukan cyberbullying.

\section{Attachment dan Cyberbullying}

Selain karakteristik kepribadian, gaya kelekatan juga berkontribusi terhadap perilaku cyberbullying (Hemphill \& Heerde, 2014; Cummings-Robeau \& Lopez, 2009). Gaya kelekatan merupakan suatu cara individu untuk menunjukkan keakraban dan kedekatan melalui perilaku yang mewakili perasaan individu pada individu lain dalam suatu hubungan interpersonal yang dijalin (Mikulincer \& Shaver, 2007). Bowlby (1988) menyatakan bahwa attachment merupakan suatu ikatan emosional yang kuat yang terbentuk melalui interaksinya dengan orang yang mempunyai arti khusus dalam kehidupannya.

Ainsworth dan Bell (1970) membagi kelekatan menjadi tiga kategori yaitu secure attachment dengan ciri anak mengasosiasikan ibu atau pengasuh sebagai suatu landasan yang aman untuk mengeksplorasi lingkungannya. Kedua tipe berikutnya yaitu kelekatan insecure-avoidant dengan ciri menghindari ibu seperti mengabaikan kehadirannya, menghindari tatapannya dan tidak berusaha mencari kedekatan dengan ibu. Kategori berikutnya adalah kelekatan insecure ambilavent/resistent yang ditandai dengan menolak ibu, misalnya dengan menendang atau mendorongnya jauh-jauh. Kedua kategori terakhir merupakan kategori insecure attachment.

Insecure attachment dikarakteristikkan dengan diri negatif dan kepercayaan berlebihan terhadap orang lain yang menyebabkan individu tergantung dengan figur pengasuhnya. avoidant attachment dikarakteristikkan dengan diri positif dan ketidakpercayaan terhadap orang lain melalui menekan afek. Sementara secure attachment memiliki keberfungsian interpersonal efektif yang mendorongnya mampu berinteraksi sosial secara adekuat. Riset 
terdahulu menunjukkan avoidant attachment berhubungan dengan harga diri rendah, depresi yang tinggi dan tingkat kesepian tinggi (Varghese \& Pistole, 2017; Mikulincer \& Shaver, 2007). Hasil dari secure attachment ini akan berimplikasi pada berkembangnya hasil pertumbuhan diri yang efektif (Mikulincer \& Shaver, 2007).

Penelitian yang dilakukan oleh Bloodworth (2015) menunjukkan bahwa seorang remaja dengan secure attachment memiliki perilaku agresif yang rendah termasuk dalam perilaku cyberbullying. Sebuah studi yang dilakukan oleh Ireland \& Power (2004) menemukan avoidant attachment berkorelasi dengan perilaku traditional bullying. Pada mahasiswa ditemukanavoidant attachment dan menghindar berhubungan secara positif dengan interpersonal aggression (Cummings-Robeau \& Lopez, 2009).

Beberapa riset terdahulu telah menguji hubungan ini, namun hasil yang didapat masih terdapat perbedaan (Krisminanti, 2015; Varghese \& Pistole, 2017) yang membutuhkan riset lebih lanjut. Selain itu kebanyakan riset dilakukan di budaya barat, sementara masih sangat sedikit riset yang dilakukan di budaya Asia (Hemphill \& Heerde, 2014; White, dkk 2016; Satalina, 2014). Diharapkan penelitian ini dapat memberikan temuan baru yang mewakili budaya di negara asia, sehingga dapat memperkaya hasil riset sebelumnya.

\section{Metode Penelitian}

\section{Partisipan}

Penelitian ini dilakukan di sebuah SMP swasta di Pekanbaru. Partisipan dalam penelitian ini berjumlah 199 siswa SMP. Teknik pengambilan sampel menggunakan cluster random sampling. Sebelum mengumpulkan data, peneliti mengurus izin riset ke pihak sekolah. Setelah mendapatkan persetujuan pihak sekolah, maka peneliti kemudian melakukan proses pengambilan. Semua siswa diinformasikan tentang tujuan riset ini, dan bagaimana mengisi kuesioner yang diberikan. Setelah semua siswa paham tentang tujuan riset dan pengisian kuesionernya, maka siswa dapat langsung mengisi kuesioner yang ada

\section{Alat Ukur}

Konsistensi internal cronbach alpha dipakai untuk menguji reliabilitas alat ukur. Sementara itu content validity digunakan untuk menguji validitas alat ukur melalui pengujian analisis rasional dengan professional judgement untuk melihat apakah item dapat mencakup keseluruhan kawasan isi objek yang hendak diukur.

Skala Cyberbullying, Skala cyberbullying yang merupakan bentuk-bentuk cyberbullying yang dikemukakan Willard (Beran \& Li, 2007) terdiri dari tujuh bentuk cyberbullying yaitu: Flaming, Online Harrassment, cyberbstalking, denigration, masquarade, outing dan exclusion. Setiap item memiliki empat pilihan alternatif jawaban, yaitu sering, kadangkadang, jarang dan tidak pernah. Penskalaan Likert digunakan dalam skala cyberbullying dengan respon favorable dimulai dari jawaban sangat sesuai (SS) diberi skor 4, sesuai (S) diberi skor 3, tidak sesuai (TS) diberi skor 2 dan sangat tidak sesuai (STS) diberi skor 1. Sementara pada jawaban Unfavorable sangat tidak sesuai (STS) diberi skor 4, tidak sesuai (TS) diberi skor 3, Sesuai (S) diberi skor 2 dan sangat sesuai (SS) diberi skor 1 . Contoh item "saya sengaja mengirim kata-kata penghinaan ke seseorang di akun sosial medianya", "saya mengirimkan gambar gambar tidak senonoh ke akun media sosial seseorang", "saya memposting rahasia pribadi seseorang di akun sosial media saya". Koefisien alpha-cronbach $=0,902$.

Skala Extraversion. Skala yang digunakan memodifikasi dari Big Five Inventory versi bahasa Inggris dengan melakukan proses back to back translation. Dimensi extraversion ini diungkap oleh delapan item yang terdiri dari lima pernyataan yang mendukung definisi konstruk (favorable) sedangkan tiga item lainnya yang berlawanan dengan definisi konstruk (unfavorable) (Ramdhani, 2012). Aspek extraversion yang digunakan dalam penelitian ini adalah Gregariousness, Assertiveness, Activity, Excitement-seeking, Positive emotions, dan warmth. Contoh item yang digunakan "saya adalah orang yang senang ngobrol" "saya termasuk orang yang mudah antusias terhadap sesuatu" "saya memiliki banyak energy untuk beraktivitas". Koefisen AlphaCronbach $=0,883$.

Skala Secure attachment, Skala secure attachment disusun berdasarkan lima aspek yang dikemukakan oleh Benokraitis (Maentiningsih, 2008). Aspek-aspek tersebut yaitu: Kehangatan terhadap orang lain, kemandirian, kedekatan dengan orang yang disayanginya, empati dan kepercayaan terhadap orang yang disayangi. Setiap item memiliki empat pilihan alternatif jawaban, yaitu (STS) sangat tidak sesuai, (TS) tidak sesuai, (S) sesuai, (SS) sangat sesuai. Contoh item yang digunakan "saya cenderung mudah dekat dengan seseorang, dan nyaman berhubungan dengan orang lain", "saya tidak cemas tentang penolakan dari orang lain" "saya tidak mudah percaya dengan niat orang lain dalam hubungan sosial". Koefisien Alpha-Cronbach = 0,868.

\section{Hasil Penelitian}

Penelitian ini menguji apakah ada hubungan antara extraversion dan secure attachment terhadap perilaku cyberbullying. Analisis regresi digunakan untuk menguji hipotesis yang diajukan. Hasil penelitian ini menunjukkan extraversion dan secure attachment memiliki hubungan yang signifikan dengan perilaku cyberbullying. Table 1 menunjukkan korelasi negatif yang sangat signifikan antara variabel extraversion dengan perilaku cyberbullying ( $\mathrm{r}=-0,345$; $\mathrm{p}=0,000$ ) dan hubungan negatif yang sangat 
signifikan antara secure attachment dengan perilaku cyberbullying $(\mathrm{r}=-0,419 ; \mathrm{p}=0,000)$.

Tabel 1. Hasil analisis korelasi secara bersama-sama

\begin{tabular}{lccccc}
\hline \multicolumn{1}{c}{ Variabel } & Mean & SD & 1 & 2 & 3 \\
\hline Cyberbullying & 47,4 & 9,63 & - & $-0,345$ & 0,419 \\
Extraversion & 83,1 & 8,11 & & - & 0,561 \\
$\begin{array}{l}\text { Secure } \\
\text { attachment }\end{array}$ & 74,8 & 6,62 & & - \\
\hline $\mathrm{F}(2,196)=23,45, \mathrm{R}^{2}=0,193$, adjusted $\mathrm{R}^{2}=0,185, \mathrm{p}=0,000$.
\end{tabular}

Tabel 2. Hasil Uji Analisis Koefisien Determinasi

\begin{tabular}{lccc}
\hline \multicolumn{1}{c}{ Model } & $\begin{array}{c}\text { Standardized } \\
\text { Coefficients } \\
\text { beta }\end{array}$ & $t$ & Sig \\
\hline $\begin{array}{l}\text { Extraversion } \\
\text { Secure }\end{array}$ & $-0,161$ & 2,082 & 0,039 \\
attachment & $-0,328$ & 4,232 & 0,000 \\
\hline
\end{tabular}

Tabel 2 menunjukkan hasil koefisien determinasi dimana masing-masing prediktor menunjukkan hasil yang signifikan. Hasil penelitian ini menunjukkan extraversion $(\beta=-0,161, \quad p=0,039)$ memiliki hubungan negatif yang signifikan dengan perilaku cyberbullying, sedangkan secure attachment $(\beta=-0,328$, $p=0,000)$ memiliki hubungan negatif yang sangat signifikan dengan perilaku cyberbullying.

\section{Diskusi}

Hasil penelitian ini menunjukkan bahwa extraversion dan secure attachment memiliki hubungan negatif yang signifikan dengan perilaku cyberbullying. Penelitian ini mengkonfirmasikan penelitian sebelumnya, seperti penelitian Ayas (2016) yang menunjukkan adanya hubungan negatif yang signifikan. Sementara itu hasil penelitian ini menyanggah penelitian sebelumnya seperti White, Fields, Hall, dan White (2016) dan Satalina (2014) yang menemukan hubungan positif antara kepribadian extraversion yang tinggi berhubungan dengan perilaku bullying dan cyberbullying. Ojedokun dan Idemudia (2013) juga menemukan hubungan positif antara kepribadian extraversion yang tinggi memiliki kecenderungan untuk melakukan cyberbullying. Sementara itu penelitian Oztürk dan Ozmen (2016) tidak menemukan hubungan yang signifikan antara kepribadian extraversion dengan perilaku cyberbullying.

Hasil penelitian ini menunjukkan bahwa kepribadian extraversion yang tinggi menurunkan kecenderungan perilaku cyberbullying, sedangkan kepribadian extraversion yang rendah (tinggi dalam kepribadian introvert) mendorong kecenderungan perilaku cyberbullying. Pertanyaan selanjutnya adalah mengapa kepribadian introvert mendorong responden dalam penelitian ini melakukan cyberbullying? Individu dengan kepribadian introvert memiliki kelemahan yaitu mereka mudah cemas, terlalu sensitif terhadap situasi di sekitarnya, sulit untuk mengekspresikan perasaannya secara terbuka, banyak memendam kemarahan, dan memiliki gaya komunikasi yang tertutup (McIntyre dkk., 2015; Mitchell dkk., 2011). Hal ini kemungkinan mendorong mereka mudah tersinggung dan marah dengan keadaan di sekitarnya, ketika ada orang lain yang menyinggung perasaannya sehingga mendorong mereka mudah melakukan cyberbullying ketika merasa tersinggung atau frustrasi. Selain itu, individu dengan kecenderungan introvert tinggi menunjukkan risiko mengalami fobia sosial dan depresi mayor kronis (Clark, Watson, \& Mineka, 1994; Trull \& Sher, 1994). Kepribadian introvert yang tinggi juga cenderung menunjukkan rendahnya tingkat kehangatan, niat suka berteman, ketegasan, aktivitas, kegembiraan, dan emosi positif (Costa \& McCrae, 1995). McIntyre, dkk (2015) menemukan individu yang introvert lebih banyak terlibat dalam compulsive internet use symptoms dibandingkan dengan individu yang extroverts, serta lebih sedikit berhubungan secara sosial dengan sekelilingnya. Artinya individu yang introvert lebih cenderung bersosialisasi melalui dunia maya, bukan dalam kehidupan nyata. Penjelasan ini lah yang melatarbelakangi mengapa individu yang introvert dalam penelitian ini cenderung terlibat dalam perilaku cyberbullying.

Sementara secure attachment juga menunjukkan hubungan negatif yang signifikan dengan perilaku cyberbullying. Hasil penelitian saat ini mengonfirmasikan penelitian sebelumnya, seperti penelitian Ireland dan Power (2004) menemukan kelekatan menghindar berkorelasi dengan perilaku bullying. Bloodworth (2015) menunjukkan bahwa seorang remaja dengan secure attachment berkorelasi dengan kecenderungan perilaku agresif yang rendah termasuk dalam perilaku bullying dan cyberbullying. Penelitian CummingsRobeau dan Lopez (2009) menemukan kelekatan cemas dan tidak aman berhubungan secara positif dengan agresi interpersonal.

Secara teori, remaja yang memiliki secure attachment akan merasa terpenuhi semua kebutuhan afeksinya (Bowbly, 1988). Kebutuhan afeksi yang terpenuhi akan mendorong perkembangan emosi yang lebih adekuat (Hemphill \& Heerde, 2014). Hal ini akan menyebabkan mereka lebih mudah memahami dan berempati terhadap orang lain, bertindak dengan pertimbangan yang matang dan menghindari perilaku yang menyakiti orang lain. Sehingga kebanyakan dari remaja yang memiliki secure attachment tinggi cenderung menghindari perilaku cyberbullying.

Bagaimana pun penelitian ini memiliki keterbatasan yang harus dipertimbangkan dalam menggeneralisasikan hasil penelitian ini. Pertama, jumlah responden yang terbatas, sehingga kurang merepresentasikan kelompok remaja sebayanya. Hasil penelitian ini hanya bisa diterapkan di sekolah 
yang menjadi sampel penelitian ini. Kedua, penelitian ini merupakan penelitian cross-sectional sehingga dimungkinkan ada beberapa bias dari hasilnya, seperti lemahnya asumsi hubungan kausal. Ketiga, penelitian ini menggunakan self report questionnaire yang dapat memungkinkan terjadinya faking bad atau faking good yang disengaja oleh responden. Karena dalam penelitian ini menggunakan siswa remaja, maka untuk menurunkan kecenderungan faking good atau faking bad, sebelum pengambilan data, peneliti memberikan informasi menyeluruh tentang penelitian ini, tujuan penelitian ini, dan penjelasan tentang tidak ada keterkaitan hasil penelitian ini dengan konsekuensi nilai akademik siswa. Peneliti juga mendorong siswa untuk mengisi dengan jujur sesuai dengan kenyataan yang dialaminya.

\section{Kesimpulan}

Hasil penelitian ini menunjukkan bahwa extraversion dan secure attachment memiliki hubungan yang signifikan dengan perilaku cyberbullying. Baik extraversion maupun secure attachment memiliki hubungan negatif yang signifikan dengan cyberbullying. Saran bagi penelitian lebih lanjut adalah untuk menggunakan sampel yang lebih representatif, agar hasil penelitiannya dapat digeneralisasikan secara luas. Selain itu penelitian lebih lanjut disarankan untuk menggunakan penelitian longitudinal sehingga dapat menguji perubahanperubahan dari variabelnya dalam pengamatan waktu berulang jangka panjang.

\section{Daftar Pustaka}

Ainsworth, M. D. S., \& Bell, S. M. (1970). Attachment, exploration, and separation: Illustrated by the behavior of one-year-olds in a strange situation. Child Development, 41(1), 49-67. doi: 10.1111/J.1467-8624.1970.Tb00975.X

Allen, J. P., \& Miga, E. M. (2010). Attachment in adolescence: A move to the level of emotion regulation. Journal of Social and Personal Relationship, 27(2), 181-190. doi: $10.1177 / 0265407509360898$

Alonso, C., \& Romero, E. (2017). Aggressors and victims in bullying and cyberbullying: A Study of personality profiles using the five-factor model. The Spanish Journal of Psychology, 20, 143-1153. doi: 10.1017/sjp.2017.73

Ang, R. P., \& Goh, D. H. (2010). Cyberbullying among adolescents: The role of affective and cognitive empathy, and gender. Child Psychiatry \& Human Development, 41(4), 387-397. doi: 10.1007/s10578-010-0176-3

Ayas, T. (2016). An Examination of the relationship between students involved and not involved in cyberbullying incidents and self-esteem and extroversion. TED EĞITIM VE BILIMM, 41(186). doi:10.15390/eb.2016.4928.

Balakrishnan, V. (2015). Cyberbullying among young adults in Malaysia: The roles of gender, age and Internet frequency. Computers in Human Behavior, 46(1), 149-157. doi: 10.1016/j.chb.2015.01.021.

Baker, Ö. E., \& Tanrıkulu, İ. (2010). Psychological consequences of cyber bullying experiences among Turkish secondary school children. Procedia - Social and Behavioral Sciences, 2(2), 2771-2776. doi: 10.1016/j.sbspro.2010.03.413.

Beran, T., \& Li, Q. (2008). The relationship between cyberbullying and school bullying. The Journal of Student Wellbeing, 1(2), 16. doi: 10.21913/jsw.v1i2.172.

Bloodworth, J. E. (2015). Attachment style and its influence on aggression. Journal of Undergraduate Research, 24.(3), 156-168. Diunduh di

https://www.mckendree.edu/academics/sch olars/bloodworth-issue-24.pdf

Bowlby, J. (1988). A secure base Parent child attachment and healthy human development. New York: Basic Books.

Brailovskaia, J., Teismann, T., \& Margraf, J. (2018). Cyberbullying, positive mental health and suicide ideation/behavior. Psychiatry Research, 267, 240-242. doi: 10.1016/j.psychres.2018.05.074.

Brewer, G., \& Kerslake, K. (2015). Cyberbulying, selfesteem, empathy and loneliness. Computers in Human Behaviour, 48, 255-260. doi: 10.1016/j.chb.2015.01.073

Camodeca, M., \& Goossens, F. A. (2005). Aggression, social cognitions, anger and sadness in bullies and victims. Journal of Child Psychology and Psychiatry, 46(2), 186-197. doi: 10.1111/j.1469-7610.2004.00347.x.

Celik, S., Atak, H., \& Erguzen, A. (2012). The effect of personality on cyberbullying among university students in Turkey. Egitim Arastirmalari Eurasian Journal of Educational Research, 49, 129-150.

Chang, F., Chiu, C., Miao, N., Chen, P., Lee, C., Chiang, J., Pan, Y. (2015). The relationship between parental mediation and Internet addiction among adolescents, and the association with cyberbullying and depression. Comprehensive Psychiatry, 57, 21-28. doi: 10.1016/j.comppsych.2014.11.013.

Chen, C. K., Waters, H, S., Hartman, M., Zimmerman,S., Miklowitz, D, J., \& Waters, E. (2013). The secure base script and the task of caring for elderly parents: implications for attachment theory and clinical practice. Attachment \& Human Development, 15(3), 332-348. doi: 10.1080/14616734.2013.782658

Clark, L. A., Watson, D., \& Mineka, S. (1994). Temperament, personality, and the mood and anxiety disorders. Journal of Abnormal 
Psychology, 103(1), 103-116. doi: 10.1037/0021-843x.103.1.103

Costa Jr., P. T., \& McCrae, R. R. (1995). Domains and facets: Hierarchical personality assessment using the revised NEO personality inventory. Journal of Personality Assessment, 64(1), 2150. doi: $10.1207 /$ s15327752jpa6401_2

Creswell, J. (2015). Riset pendidikan perencanaan, pelaksanaan, dan evaluasi riset kualitatif \& kuantitatif (edisi kelima). Yogyakarta: Pustaka Pelajar.

Collin, V. L. (1996). Human attachment. New York : McGraw Hill.

Collins, N. L., \& Read, S. J. (1990). Adult attachment, working models, and relationship quality in dating couples. Journal of Personality and Social Psychology. 5(4), 644-663. doi: 10.1037/0022-3514.58.4.644

Cummings-Robeau, T. L., \& Lopez, F. G. (2009). Attachment-related predictors of college students' problems with interpersonal sensitivity and aggression. Journal of Social and Clinical Psychology, 28(3), 364-391. doi: 10.1521/jscp.2009.28.3.364

Ditch the Label. (2013). Cyberbullying statistics: what they tell us. Diakses dari http://www.ditchthelabel.org/cyber-bullyingstatistics-what-they-tell-us /

Disa, M. (2011). Faktor-Faktor yang memengaruhi cyberbullying pada remaja. (Dipresentasikan dalam seminar APSIFOR Indonesia, di Semarang, 16-17 November 2010).

Ervika, E. (2005). Kelekatan (attachment) pada anak. E-USU Repository. Medan: Program Studi Psikologi, Fakultas Kedokteran, Universitas Sumatera Utara.

Espelage, D. L., Bosworth, K., \& Simon, T. R. (2000). Examining the social context of bullying behaviors in early adolescence. Journal of Counseling and Development, 78(8), 326-333. doi: 10.1002/j.1556-6676.2000.tb01914.x

Gibb, Z. G., \& Devereux, P. G. (2014). Who does that anyway? Predictors and personality correlates of cyberbullying in college. Computers in Human Behavior, 38, 8-16. doi: 10.1016/j.chb.2014.05.009.

Gilliland, R., Star, J.B., Hansen, B., \& Carpenter, B (2014). Relationship attachment styles in a sample of hypersexual patients, Journal of Sex \& Marital Therapy. 41(6), 581-592. doi: 10.1080/0092623x.2014.958787.

Gradinger, P., Strohmeier, D., \& Spiel, C. (2009). Traditional Bullying and Cyberbullying. Zeitschrift Für Psychologie/Journal of Psychology, 217(4), 205-213. doi: 10.1027/0044-3409.217.4.205

Graham, R., \& Wood, F. R. (2019). Associations between cyberbullying victimization and deviant health risk behaviors. The Social Science Journal, 56(2), 183-188. doi: 10.1016/j.soscij.2018.05.005.
Hazan, C., \& Shaver, P. (1987). Romantic love conceptualized as an attachment process. Journal Personality and Social Psychology, 52(3), 511-524. doi: 10.1037//00223514.52.3.511

Hemphill, S. A. \& Heerde, J. A. (2014). Adolescent Predictors of Young Adult Cyberbullying Perpetration and Victimization Among Australian Youth. Journal of Adolescent Health 55(4), 580-587. doi: 10.1016/j.jadohealth.2014.04.014

Hinduja, S., \& Patchin, J. W. (2010). Cyberbullying and self esteem. Journal of School Health, 80(12), 614-621. doi:10.1111/j.17461561.2010.00548.x

Hinduja, S., \& Patchin, J. W. (2014). Cyberbullying: Identification, prevention \& Response. Cyberbullying Research Center.

Ireland, J. L., \& Power, C. L. (2004). Attachment, emotional loneliness, and bullying behavior: A study of adult and young offenders. Aggressive Behavior, 30(4), 298-312. doi: 10.1002/ab.20035.

John, O. P., \& Srivastava, S. (1999). The Big-Five trait taxonomy: History, measurement, and theoretical perspectives. In L. A. Pervin \& O. P. John (Eds.), Handbook of personality: Theory and research. 2, 102-138, New York: Guilford Press.

Khosa, N. (2016). How personality effects victim's response to cyberbullying. Unpublished thesis. Iowa: Iowa State University.

Kowalski, R, M., Limber, S.P., \& Agatston, P. W. (2012). Cyberbullying: Bullying in the digital age. Second Edition. USA. Wiley Blackwell.

Kowalski, R. M., \& Limber, S. P. (2013). Psychological, physical, and academic correlates of cyberbullying and traditional bullying. Journal of Adolescent Health, 53, 13-20. doi: 10.1016/j.jadohealth.2012.09.018

Krisminanti, C. V. (2015). Hubungan antara dimensi extraversion dan openness to experience dalam kepribadian big five dengan kecenderungan remaja melakukan cyberbullying. (Skripsi tidak diterbitkan). Fakultas Psikologi Universitas Sanata Dharma, Yogyakarta.

Lee, C., \& Shin, N. (2017). Prevalence of cyberbullying and predictors of cyberbullying perpetration among Korean adolescents. Computers in Human Behavior, 68, 352-358. doi: 10.1016/j.chb.2016.11.047

Lee, K., \& Ashton, M. C. (2012). The $H$ factor of personality. Ontario, Canada: Wilfrid Laurier. University Press.

Li, Q. (2007). New bottle but old wine: A research of cyberbullying in schools. Computers in Human Behavior, 23(4), 1777-1791. doi: 10.1016/j.chb.2005.10.005.

Macaulay, P. J. R., Betts, L. R., Stiller, J., \& Kellezi, B. (2018). Perceptions and responses towards cyberbullying: A systematic review of teachers in the education system. Aggression 
and Violent Behavior, 43, 1-12. doi: 10.1016/j.avb.2018.08.004.

Leung, A. N. M., Wong, N., \& Farver, J. M. (2018). Cyberbullying in Hong Kong Chinese students: Life satisfaction, and the moderating role of friendship qualities on cyberbullying victimization and perpetration. Personality and Individual Differences, 133, 7-12. doi: 10.1016/j.paid.2017.07.016.

Maentiningsih, D (2008). Hubungan antara kelekatan aman dengan motivasi berprestasipada remaja. Jurnal Psikologi

McIntyre, E., Wiener, K. K. K., \& Saliba, A. J. (2015). Compulsive Internet use and relations between social connectedness, and introversion. Computers in Human Behavior, 48, 569-574. doi: 10.1016/j.chb.2015.02.021.

Mikulincer, M., \& Shaver, P. R. (2015). The psychological effects of the contextual activation of security-enhancing mental representations in adulthood. Current Opinion in Psychology, 1, 18-21. doi: 10.1016/j.copsyc.2015.01.008.

Mitchell, M. E., Lebow, J. R., Uribe, R., Grathouse, H., Shoger, W. (2011). Internet use, happiness, social support and introversion: A more fine grained analysis of person variables and internet activity. Computers in Human Behavior, 27(5), 1857-1861. doi: 10.1016/j.chb.2011.04.008

Monks, C. P., Smith, P. K., Naylor, P., Barter, C., Ireland, J. L., \& Coyne I. (2009). Bullying indifferent context: Commonalities, differences and the role of theory. Aggression and Violent Behavior, 14, 146-156. doi: 10.1016/j.avb.2009.01.004

Murphy, L., Eduljee, N. B., Croteau, K., \& Parkman, S. (2017). Extraversion and introversion personality type and preferred teaching and classroom participation: A pilot study. Journal of Psychosocial Research, 12(2), 437-450. Diunduh dari https://www.researchgate.net/publication/3 24503633_Extraversion_and_Introversion_Pe rsonality_Type_and_Preferred_Teaching_and_ Classroom_Participation_A_Pilot_Study

Ojedokun O., \& Idemudia, E. S. (2013) The moderating role of emotional intelligence between PEN personality factors and cyberbullying in a student population. Life Science Journal, 10(3), 1924-1930. Diunduh dari https://www.lifesciencesite.com/lsj/life1003/ 285_20452life1003_1924_1930.pdf

Öztürk, E., \& Özmen, S. K. (2016). The relationship of self-perception, personality and high school type with the level of problematic internet use in adolescents. Computers in Human Behavior, 65, 501-507. doi:10.1016/j.chb.2016.09.016.

Olweus, D. (2012). Cyberbullying: An overrated phenomenon? European Journal of Developmental Psychology, 9(5), 520-538. doi:10.1080/17405629.2012.682358
Pallesen, S., Nielsen, M. B., Magerøy, N., Andreassen, C. S., \& Einarsen, S. (2017). An experimental study on the attribution of personality traits to bullies and targets in a workplace setting. Frontiers in Psychology, 8. doi: 10.3389/fpsyg.2017.01045.

Panfile, T. M., \& Laible, D. J. (2012). Attachment security and child's empathy: The mediating role of emotion regulation. Merrill-Palmer Quarterly, 58(1), 1-21. doi: 10.1353/mpq.2012.0003

Pervin, L. A., Cervone, D., \& John, O.P. (2010). Psikologi Kepribadian Teori dan Penelitian. Edisi Kesembilan. Jakarta : Kencana.

Peled, Y. (2019). Cyberbullying and its influence on academic, social, and emotional development of undergraduate students. Heliyon, 5(3), e01393. doi: 10.1016/j.heliyon.2019.e01393.

Peter, I.-K., \& Petermann, F. (2018). Cyberbullying: A concept analysis of defining attributes and additional influencing factors. Computers in Human Behavior, 86, 350-366. doi: 10.1016/j.chb.2018.05.013.

Parritz, R.H., \& Troy, M.F. (2014). Disorders of childhood: development and psychopathology second edition. Wadsorth: Cengage Learning.

Reed, K. P., Cooper, R. L., Nugent, W. R., \& Russell, K. (2015). Cyberbullying: A literature review of its relationship to adolescent depression and current intervention strategies. Journal of Human Behavior in the Social Environment, 26(1), 37-45. doi: 10.1080/10911359.2015

Quarshie, O. H. (2012). The impact of computer technology on the development of children in Ghana. Journal of Emerging Trends in Computing and Information Sciences, 3(5),717722.

Ramdhani, N. (2012). Adaptasi bahasa dan budaya inventori big five. Jurnal Psikologi, 39(2), 189207.

Riccelli, R., Toschi, N., Nigro, S., Terracciano, A., \& Passamonti, L. (2017). Surface-based morphometry reveals the neuroanatomical basis of the five-factor model of personality. Social Cognitive and Affective Neuroscience, nsw175. doi: 10.1093/scan/nsw175.

Safaria, T. (2016). Prevalence and impact of cyberbullying in a sample of indonesian junior high school students. The Turkish Online Journal of Educational Technology, 15(1), 8291.

Safaria, T. (2015). Are daily spiritual experiences, self-esteem, and family harmony predictors of cyberbullying among high school student? International Journal of Research Studies in Psychology, 4(3). doi: 10.5861/ijrsp.2015.1103.

Saklofske, D.H., Eysenck, H.J., Eysenck, S.B.G., Stelmack, R.M. \& Revelle, W. (2012). Extraversion-Introversion. Encyclopedia of Human Behavior (Second Edition), 150-159. 
Satalina, D. (2014). Kecenderungan perilaku cyberbullying ditinjau dari tipe kepribadian extraversion dan introvert. Jurnal Ilmiah Psikologi Terapan, 02(2), 294-310.Diunduh dari http://ejournal.umm.ac.id/index.php/jipt/art icle/viewFile/2003/2105

Hong, J. S., Kim, D. H., Thornberg, R., Kang, J. H., \& Morgan, J. T. (2018). Correlates of direct and indirect forms of cyberbullying victimization involving South Korean adolescents: An ecological perspective. Computers in Human Behavior, 87, 327-336. doi: 10.1016/j.chb.2018.06.010.

Tokunaga, R. S. (2010). Following you home from school: A critical review and synthesis of research on cyberbullying victimization. Computers in Human Behavior, 26(3), 277287. doi: 10.1016/j.chb.2009.11.014.

Trull, T. J., \& Sher, K. J. (1994). Relationship between the five-factor model of personality and Axis I disorders in a nonclinical sample. Journal of Abnormal Psychology, 103(2), 350-360. doi: 10.1037/0021-843x.103.2.350

Wang, C.-C., \& Chang, Y.-T. (2010). Cyber relationship motives: Scale development and validation. Social Behavior and Personality: An International Journal, 38(3), 289-300. doi: 10.2224/sbp.2010.38.3.289.

Watts, L. K., Wagner, J., Velasquez, B., \& Behrens, P. I. (2017). Cyberbullying in higher education: A literature review. Computers in Human
Behavior, 69, 268-274. doi: 10.1016/j.chb.2016.12.038.

White, H.M., Fields, J., Hall, R. T., \& White, J, S. (2016). Application of actor level social characteristic indicator Selection for the precursory detection of bullies in online social networks. Proc Of SPIE, 9826.

Wiguna, T., Irawati Ismail, R., Sekartini, R., Setyawati Winarsih Rahardjo, N., Kaligis, F., Prabowo, A. L., \& Hendarmo, R. (2018). The gender discrepancy in high-risk behaviour outcomes in adolescents who have experienced cyberbullying in Indonesia. Asian Journal of Psychiatry, 37, 130-135. 130-135. doi: 10.1016/j.ajp.2018.08.021.

Willard, N. E. (2007). Cyberbullying and cyberthreats: Responding to the challenge of online social aggression, threats, and distress. IL: Research Press.

Wong, N., \& McBride, C. (2018). Fun over conscience: Fun-seeking tendencies in cyberbullying perpetration. Computers in Human Behavior, 86, 319-329. doi: 10.1016/j.chb.2018.05.009.

Zych, I., Baldry, A. C., Farrington, D. P., \& Llorent, V. J. (2019). Are children involved in cyberbullying low on empathy? A systematic review and meta-analysis of research on empathy versus different cyberbullying roles. Aggression and Violent Behavior, 45, 83-97. doi: 10.1016/j.avb.2018.03.004. 